\title{
WOOD PROPERTIES COMPARATION OF CEDRELA ODORATA FROM TREES IN AGROFORESTRY AND IN PURE PLANTATION
}

\author{
Beatriz Segura-Elizondo, Róger Moya \\ Instituto Tecnológico de Costa Rica-Escuela de Ingeniería Forestañ \\ Escuela de Ingeniería Forestal \\ Costa Rica \\ (Received August 2020)
}

\begin{abstract}
The aim of this work was to compare the general, physical, mechanical, chemical and energy properties of the wood from Cedrela odorata trees growing in two agroforestry condition (tree-agroforestry) with Theobroma cacao ( 9 and 10 years old), with a ten-year-old $C$. odorata tree growing in pure plantation (tree-plantation). The results showed that there growing in agroforestry presented higher heartwood diameter $(6.7$ to $7.6 \mathrm{~cm}$ ) and heartwood (approx. 17\%) and lower bark (12-13\%) and sapwood (69-70\%) percentages than trees in pure plantation. In addition, this tendency was observed through different heights of the tree. Moreover, wood from 9-tree-agroforestry presented highest specific gravity and volume shrinkage. Then wood from this growing condition presented highest strength in axial hardness and flexure relative, and extractives in cold water and ethanol-toluene. No differences were observed between the energy properties. In general, wood from trees in agroforestry present better properties than the trees growing in pure plantation. According with these results, the potential of agroforestry systems relative to pure plantations, as regards to differences in tree growth produced by crop fertilization, pruning and other management measures to which the agricultural crop is subjected, which can give the wood qualities different from those found at earlier ages.
\end{abstract}

KEYWORDS: Tropical wood, cedarwood, Spanish cedar, growing condition, farmer trees.

\section{INTRODUCTION}

Cedrela odorata Linneo belongs to the Meliaceae family. It is one of the most economically important species in America (Somarriba et al. 2013). It grows in natural forests of the life zones tropical wet forest, sub-tropical humid forest and tropical dry forest (Jaimez 2013). The quality of C. odorata wood is excellent and is used for light constructions, interior design, ship construction (decks and panelling) and general woodworks (Cordero 2004). On the other hand, 
C. odorata has been planted in pure forest plantations for timber production (Jaimez 2013). However, the greatest potential observed so far is its good growth in association with other agricultural crops in agroforestry systems (Somarriba et al. 2014, Jaimez 2013). The tree species most used in agroforestry are those timbers presenting good size and shape, or those that provide a fresh environment to the plantation: Cedrela odorata, along with other species, has this potential (Somarriba et al. 2014).

Many tree species used in agroforestry have great potential for timber uses (Tscharntke et al. 2011). It has been pointed out that the intensive management in tree-crop associations propitiates an improvement of the wood properties compared to other growth conditions, such as pure plantations or natural forests (Tscharntke et al. 2011, Tenorio and Moya 2019). In addition, tree aging, frequent crop fertilization, as well as pruning application and the management to which the agricultural product is subjected in general, are factors that could give the wood different qualities from those of wood extracted from trees growing in natural forest or in pure forest plantations (Somarriba et al. 2014, Tenorio and Moya 2019, Kouakou et al. 2016). Wood production associated to agroforestry is an attractive economic activity in Costa Rica, as it complements other measures of optimization and diversification of farm products (Somarriba and Beer 2011). Several studies have shown the economic importance and growth of $C$. odorata planted in agroforestry (Somarriba and Beer 2011). The main studies conducted on C. odorata in agroforestry concentrate on silvicultural aspects (Tixier and Salazar-Dìz 2019). Special interest has been shown in recent years on finding information about the quality of the wood of $C$. odorata in agroforestry (Tenorio and Moya 2019, Rigg-Aguilar and Moya 2018).

Specifically, Rigg-Aguilar and Moya (2019) studied the wood of trees of two varieties of C. odorata growing in an agroforestry, finding that some properties differed between both varieties regarding the percentages of bark and the volumetric shrinkage, moisture content (MC), green density, flexural MOR and MOE, longitudinal compression and tensile strength. In addition, Tenorio and Moya (2019) studied the properties of wood from trees from four agroforestry at different ages ( 7 to 11 years). These authors found that the analysed wood presented few differences between heights and ages. So far, the quality of wood from trees from agroforestry systems (tree-agroforestry) has not been compared to wood from pure plantations (tree-plantation) of $C$. odorata, in particular regarding physical, chemical, dasometric and mechanical properties. Therefore, more research was needed on this respect to determine the characteristics of wood under tree-agroforestry compared to wood under tree-plantation conditions. Hence, the objective of this work was to compare the dasometric, physical mechanical, chemical and energy properties of the wood from nine and ten year old tree-agroforestry of $C$. odorata with $T$. cacao, with a ten year old C. odorata tree-plantation.

\section{MATERIAL AND METHODS}

\section{Study site and plantations}

Trees from three different plantations were sampled: trees growing in nine- and ten-year-old agroforestry systems (9-tree-agroforestry) and (10-tree-agroforestry) combining Cedrela odorata and Theobroma cacao (cacao) and trees from a ten-year-old pure C. odorata plantation (10-treeplantation). The plantations were located in Turrialba $\left(9^{\circ} 58^{\prime} 02^{\prime \prime} \mathrm{N}-83^{\circ} 36^{\prime} 44^{\prime \prime} \mathrm{W}\right)$, Costa Rica in two sites close to one another. The three plantations were planted with initial spacing of $3 \times 3 \mathrm{~m}$. Pruning and thinning began after two years and weed clearing was done two or three times a year, depending on weed growth. Ferns were planted in the pure plantation (10-tree-plantation) during the first year, and after that year, neither thinning nor weeding were applied. 
Experimental design and sampling

Nine trees were randomly selected from each of the plantations of $C$. odorata. The sampled trees had a diameter similar to the average diameter of the plantation (Moya and Muñoz 2010), which was previously obtained by measuring the diameters of the established plots (Tab. 1). The cut trees had straight trunks, normal branching and no symptoms of diseases or pests. The commercial height was measured in these trees and represents the height when the diameter is $10 \mathrm{~cm}$.

Tab. 1: Dasometric parameters of Cedrela odorata trees growing in an agroforestry system with Theobroma cacao and growing in pure plantation.

\begin{tabular}{|l|c|c|c|c|}
\hline \multicolumn{1}{|c|}{ Ages } & Density $\left(\right.$ trees$\left.\cdot \mathrm{ha}^{-1}\right)$ & Total height $(\mathrm{m})$ & $\begin{array}{c}\text { Diameter breast } \\
\text { height }(\mathrm{cm})\end{array}$ & $\begin{array}{c}\text { Average growth } \\
\text { rate }\left(\mathrm{cm}^{-y e a r s}{ }^{-1}\right)\end{array}$ \\
\hline 9-tree-agroforestry & 1000 & 26.2 & 22.8 & 2.5 \\
\hline 10-tree-agroforestry & 720 & 28.0 & 23.9 & 2.4 \\
\hline 10-tree-plantation & 960 & 26.5 & 17.8 & 1.8 \\
\hline
\end{tabular}

Sampling within the trees consisted of the extraction of cross-section discs and logs. In the case of the logs, two sections were obtained: one from the base to breast height diameter (DBH) and the other from the DBH to $25 \%$ of the commercial height. In the case of the cross-section discs, these were $3.0 \mathrm{~cm}$ thick and were cut at the base, at DBH, and at 25\%,50\%, 75\% and $100 \%$ of the commercial height.

\section{Dasometric properties}

For each cross section, tree diameter, bark (thickness and total area percentage), sapwood (thickness and total area percentage) and heartwood (diameter and total area percentage) were determined. Two perpendicular lines were drawn crossing the centre of each disc, one in the north-south direction and the other in east-west direction. Total diameter, diameter without bark and heartwood diameter were measured in both directions drawn on the disc. Bark thickness was calculated as difference between total diameter and diameter without bark and sapwood thickness as the difference between total diameter and heartwood diameter. The percentages of bark, sapwood and heartwood were calculated relative to the area of these sections and the total disc area.

\section{Physical and mechanical properties}

The physical properties determined were green density, specific gravity, green MC, volume and tangential and radial total shrinkage. These properties were determined in each disc from the trunk, for each percentage of commercial height ( $0 \%, \mathrm{DBH}, 25 \%, 50 \%, 75 \%, 100 \%)$, except for the tangential and radial shrinkages, which were only determined for the $\mathrm{DBH}$. A $3.0 \mathrm{~cm}$-wide piece was cut from each cross section, pith included. The section was divided at the pith, obtaining two samples. To determine the radial and tangential shrinkage, two pieces (radial and tangential) were cut, with dimensions $2.5 \times 2.5 \times 10 \mathrm{~cm}$. Green density is calculated by ratio of green weight/green volume, specify gravity, different shrinkage and MC according to ASTM D-143 (ASTM, 2014). The mechanical strengths determined were: static flexure, Janka hardness, compression parallel to the grain and shear strength parallel to the grain, following the ASTM D143-14 standards (ASTM, 2014). The logs obtained from the sampled trees were sawn and the pieces were dried to obtain $12 \% \mathrm{MC}$ condition. For each one of the mechanical tests, 18 samples per age were prepared. 
Chemical and energy properties

Three samples of each age were used for determination of following properties and the standards were: method T222 om-02 (Tappi 2002) for lignin content; Seifert (1960) for cellulose; the ASTM D1110-84 (ASTM 2013a) for extractives in water (hot and cold conditions); the ASTM D 1109-84 for sodium hydroxide (ASTM 2013b); ASTM D1107-96 for the ethanoltoluene solution (ASTM 2013c); ASTM D1108-96 (ASTM 2013d) for dichloromethane (ASTM 2013e); ASTM D1102-84 standard (ASTM 2013e) for ash content, ASTM D1762-84 (ASTM 2013f) for volatile content, respectively and ASTM D-5865 standard (ASTM 2013g) for determination of the calorific power. The CHNS vario El cube series 19171074 was utilized for determination of the contents of carbon $(\mathrm{C})$, hydrogen $(\mathrm{H})$, nitrogen $(\mathrm{N})$ and sulphur $(\mathrm{S})$.

\section{Statistical analysis}

A general statistical description (average and coefficient of variation) was applied for all wood properties. Then, an ANOVA (analysis of variance) was performed to determine the effect of different tree growth conditions (agroforestry and plantation). This analysis was applied only to the properties at $\mathrm{DBH}$. Tukey multiple range test $(\mathrm{P}<0.05)$ was applied to test the significant differences between the physical, mechanical, dasometric and chemical properties. The statistical programs used were SAS and Info Stat.

\section{RESULTS AND DISCUSSION}

\section{Dasometric properties}

In relation to the dasometric properties at $\mathrm{DBH}$, statistical differences were observed in general in all the parameters analyzed, with the exception of bark and sapwood thickness, for which there were no statistical differences (Tab. 2). Regarding the total diameter, 10-treeplantation trees showed statistical differences with trees growing in agroforestry. In relation to bark, it was only found difference in bark percentage. With respect to sapwood percentage, trees in agroforestry systems did not show statistical differences between them, but statistic differences were observed relative to 10 -tree-plantation. The diameter and percentage of heartwood was the highest in 9-tree-agroforestry.

Tab. 2: Comparison of the properties of different tree tissues at diameter at breast height of Cedrela odorata trees growing in agroforestry systems with Theobroma cacao and growing in pure plantation.

\begin{tabular}{|l|l|c|c|c|}
\hline Type of tissue & \multicolumn{1}{|c|}{ Parameter } & 9-tree-agroforestry & 10- tree-agroforestry & 10- tree-plantation \\
\hline \multirow{2}{*}{ Bark } & Thickness $(\mathrm{cm})$ & $0.59^{\mathrm{A}}(18.7)$ & $0.56^{\mathrm{A}}(22.2)$ & $0.61^{\mathrm{A}}(21.9)$ \\
\cline { 2 - 5 } & Percentage & $13.85^{\mathrm{A}}(19.9)$ & $12.95^{\mathrm{B}}(23.9)$ & $15.00^{\mathrm{C}}(12.1)$ \\
\hline \multirow{2}{*}{ Sapwood } & Thickness $(\mathrm{cm})$ & $4.60^{\mathrm{A}}(28.9)$ & $4.44^{\mathrm{A}}(27.6)$ & $4.55^{\mathrm{A}}(22.0)$ \\
\cline { 2 - 5 } & Percentage & $70.75^{\mathrm{AB}}(7.4)$ & $68.57^{\mathrm{A}}(13.4)$ & $72.96^{\mathrm{B}}(5.7)$ \\
\hline \multirow{2}{*}{ Heartwood } & Diameter $(\mathrm{cm})$ & $6.69^{\mathrm{A}}(36.9)$ & $7.59^{\mathrm{B}}(48.3)$ & $5.56^{\mathrm{C}}(37.5)$ \\
\cline { 2 - 6 } & Percentage & $14.90^{\mathrm{A}}(31.9)$ & $17.97^{\mathrm{B}}(49.4)$ & $11.47^{\mathrm{A}}(38.0)$ \\
\hline \multicolumn{2}{|r|}{ Diameter at breast height } & $17.06^{\mathrm{A}}(28.4)$ & $17.59^{\mathrm{A}}(30.9)$ & $15.87^{\mathrm{B}}(24.7)$ \\
\hline
\end{tabular}

Note: Different letters between ages and same wood property mean statistically different at $99 \%$. The values between parentheses represent the coefficient of variation. 
With regard to tree height variations, the thickness of the heartwood, sapwood and bark decreased from the base to the commercial height (Fig. 1a-c).

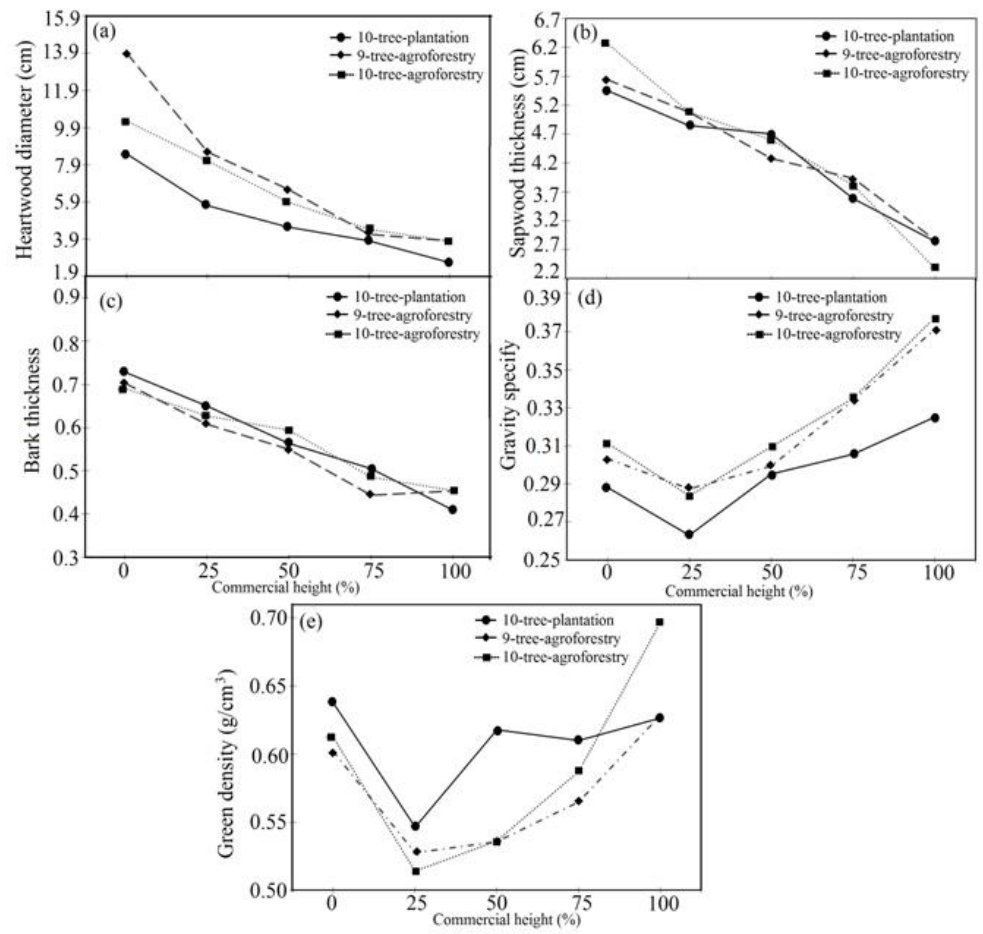

Fig. 1: Heartwood diameter (a), sapwood thickness (b), bark thickness (c), specific gravity, (d) and green density (e) in relation to commercial height of Cedrela odorata from trees growing in an agroforestry system with Theobroma cacao and growing in a pure plantation.

Concerning the differences in the two growth systems used (agroforestry systems and pure plantation), the heartwood diameter of agroforestry systems at any height is greater than in 10-tree-plantation (Fig. 1a). The 10-tree-plantation showed smaller diameter at all tree heights. In relation to sapwood and bark thickness (Fig. 1b,c), the three ages showed very similar thickness at different heights.

With respect to variations with the height of the tree (Tab. 3), it was found that the heartwood percentage of trees growing in agroforestry systems at any height was higher than heartwood percentage for trees growing in the 10-tree-plantation condition. Sapwood percentage and heartwood percentage behaved inversely: there was a lower sapwood percentage at all heights in trees growing agroforestry. Regarding the bark percentage, trees in 10-tree-plantation was higher than trees in agroforestry. 
Tab. 3: Heartwood, sapwood and bark percentage of trees properties in different commercial height of Cedrela odorata from trees growing in agroforestry system with Theobroma cacao and growing in pure plantation.

\begin{tabular}{|c|c|c|c|c|}
\hline Type of tissue & $\begin{array}{c}\text { Commercial } \\
\text { height }(\%)\end{array}$ & 9-tree-agroforestry & 10- tree-agroforestry & 10- tree-plantation \\
\hline \multirow{5}{*}{ Heartwood (\%) } & 0 & $17,91^{\mathrm{A}}(22.7)$ & $27.38^{\mathrm{B}}(19.1)$ & $16.50^{\mathrm{C}}(14.6)$ \\
\hline & 25 & $17.02^{\mathrm{A}}(7.2)$ & $18.65^{\mathrm{A}}(16.9)$ & $11.41^{\mathrm{B}}(9.8)$ \\
\hline & 50 & $12.76^{\mathrm{A}}(9.6)$ & $16.94^{\mathrm{B}}(13.8)$ & $8.93^{\mathrm{B}}(15.0)$ \\
\hline & 75 & $11.61^{\mathrm{A}}(12.6)$ & $10.84^{\mathrm{A}}(9.5)$ & $9.19^{\mathrm{C}}(19.0)$ \\
\hline & 100 & $15.42^{\mathrm{A}}(14.3)$ & $14.67^{\mathrm{A}}(20.6)$ & $7.49^{\mathrm{B}}(11.5)$ \\
\hline \multirow{5}{*}{ Sapwood (\%) } & 0 & $70.88^{\mathrm{A}}(9.0)$ & $62.33^{\mathrm{B}}(7.4)$ & $69.88^{\mathrm{A}}(9.6)$ \\
\hline & 25 & $69.81^{\mathrm{A}}(20.4)$ & $69.03^{\mathrm{A}}(21.9)$ & $72.87^{\mathrm{B}}(21.0)$ \\
\hline & 50 & $72.49^{\mathrm{A}}(21.6)$ & $69.44^{\mathrm{B}}(24.5)$ & $76.05^{\mathrm{C}}(23.6)$ \\
\hline & 75 & $73.45^{\mathrm{A}}(16.5)$ & $75.09^{\mathrm{B}}(32.4)$ & $73.83^{\mathrm{A}}(22.2)$ \\
\hline & 100 & 65.19A (13.0) & $67.33^{\mathrm{B}}(32.4)$ & $74.28 \mathrm{C}(16.8)$ \\
\hline \multirow{5}{*}{ Bark (\%) } & 0 & $11.14^{\mathrm{A}}(10.1)$ & $10.25^{\mathrm{A}}(10.3)$ & $13.48^{\mathrm{B}}(7.7)$ \\
\hline & 25 & $12.58^{\mathrm{A}}(15.5)$ & $11.83^{\mathrm{A}}(17.3)$ & $15.02^{\mathrm{B}}(13.3)$ \\
\hline & 50 & $14.23^{\mathrm{A}}(13.2)$ & $13.13^{\mathrm{A}}(20.7)$ & $14.42^{\mathrm{A}}(13.4)$ \\
\hline & 75 & $14.56^{\mathrm{A}}(16.4)$ & $13.45^{\mathrm{A}}(20.9)$ & $16.13^{\mathrm{A}}(9.7)$ \\
\hline & 100 & $18.43^{\mathrm{A}}(14.0)$ & $17.04^{\mathrm{A}}(35.5)$ & $17.23^{\mathrm{A}}(11.0)$ \\
\hline
\end{tabular}

Note: Different letters between ages and same wood property mean statistically different at $99 \%$. The values in parentheses represent the coefficients of variation.

Leyva and Erguera (2014) and Rigg-Aguilar and Moya (2018) showed that the diameter values between 10 and $15 \mathrm{~cm}$ for this species in agroforestry systems, hence these values are within the range of values obtained in this study (Tab. 2). On other hands, Tenorio and Moya (2019) and Rigg-Aguilar and Moya (2018) reported similar dasometric properties of C. odorata trees than the results of this study.

Greater diameter is evident in 9-tree-agroforestry and 10-tree-agroforestry compared to 10-tree-plantation, at the different heights studied and at the DBH (Tabs. 2-4 and Fig. 1). Diameter growth of $C$. odorata trees, as for any other species, is greater when growing in agroforestry systems, compared to diameter growth in pure plantations. Frequent crop fertilization, in this case T. cacao, as well as the frequent application of pruning to handle the shade and in general the management to which the agricultural product is subjected in an agroforestry systems, provides better conditions for the growth of the tree than when growing under conditions of pure forest plantation (Jaimez 2013). In fact, trees growing in agroforestry systems require shorter rotations than pure plantations (Montagnini and Nair 2004, Kouakou et al. 2016). Therefore, the greater diameter growth results in differences in the dasometric characteristics of the tree, as occurred in the present study with heartwood and sapwood, although not in bark thickness (Tabs. 2-4, Fig. 1), which is related to tree growth (Taylor et al. 2002).

The heartwood diameter showed an increase with increasing tree diameter (Taylor et al. 2002), therefore, an increase in the heartwood percentage and a decrease in the sapwood percentage. This behaviour was evident in the trees of $C$. odorata of the present study, where the trees growing in agroforestry systems produce greater diameter development and heartwood percentage than trees growing in a pure plantation (Tabs 2 and 3, Fig. 1a). Heartwood formation results from the death of the parenchyma and accumulation of substances (extractives) in the inner 
part of the tree, and is regulated by the physiological behavior of the enzymes in the sapwood, which in turn is regulated by growth conditions (Taylor et al. 2002). Knowledge about heartwood formation is scarce in tropical species (Taylor et al. 2002) and very limited for trees growing in fast growth tropical conditions (Moya et al. 2014). However, heartwood increase can be explained by the tree's need to increase the physiological processes of the enzymes in the sapwood in order to achieve the development observed in the trees in agroforestry systems conditions.

In relation to the bark, the greatest source of variation is within the species, tree age and height (Paine et al. 2010). This behavior is consistent with results found in C. odorata trees growing in agroforestry systems and pure plantations (Tabs. 2 and 4; Fig. 1c). According to Wilson and Witkowski (2003), bark variation during the first years of growth of the tree before flowering, is low. This is because it is unnecessary for the tree to invest heavily in creating a thick tissue, in contrast with bigger trees that need more protection for the various tissues and to produce elements for conduction. This physiological behaviour can also explain the little variation of the bark thickness in C. odorata growing in agroforestry systems compared to trees in pure plantation. However, due to greater diameter increase in 9-tree-agroforestry and 10-tree-agroforestry, the tree needs more protection all around its circumference, resulting in increased bark percentage in trees growing in agroforestry systems relative to pure plantations. This behavior is consistent with reports from Tenorio and Moya (2019) and Rigg-Aguilar and Moya (2018).

\section{Physical and mechanical properties}

There were statistical differences in all parameters analysed, in general, except for the green density, green moisture content and shrinkages (transversal, radial and volumetric) which showed no statistical differences between 10-tree-plantation, 9-tree-agroforestry and 10-tree-agroforestry conditions (Tab. 4). 9-tree-agroforestry and 10-tree-agroforestry conditions presented no statistical differences in specific gravity (SG), as opposed to 10-tree-plantation, which presented less SG. Regarding the variation of SG and green density with the tree height, it was found that these parameters decreased from the base up to $25 \%$ of the commercial height, and then increased up to $100 \%$ commercial height in the three conditions (Fig. 1e). In general, the SG was higher in 9-tree-agroforestry (Fig. 1d), but for green density was the highest in 10-treeplantation condition (Fig. 1e).

The mechanical properties presented no statistical differences as regards to lateral and axial hardness, tangential and radial shear strength, compression parallel to the grain and tensile strength, for woods from 9-tree-agroforestry and 10-tree-agroforestry, as well as for trees growing in 10-tree-plantation condition. Flexure parameters (MOR and MOE) of trees from 9 -tree-agroforestry and 10-tree-agroforestry conditions presented lower values than in trees from 10-tree-plantation.

Tenorio and Moya (2019) and Rigg-Aguilar and Moya (2018) reported SG, green density and their variation across of trunk and mechanical properties for Cedrela trees in pure plantation agree with those obtained in this study (Fig. 1e-f, Tabs. 3-4). In relation to mechanical properties, For $C$. odorata, some researchers reported higher mechanical properties. For example, 65.9 MPa resistance is reported for MOR (Bárcenas-Pazos et al. 2014) and $6700 \mathrm{MPa}$ for MOE (Venson et al. 2008) in flexural test, with a lower MOR value obtained in this study.

The SG is a wood quality evaluation parameter that is related to many properties (MullerLandau 2004), therefore, any change or difference in this parameter in trees growing in an agroforestry system or in a pure plantation, affects other important wood properties (Tixier and Salazar-Díaz 2019). Trees growing under 9-tree-agroforestry and 10-tree-agroforestry conditions showed higher SG than trees growing in the 10-tree-plantation condition (Tab. 4, Fig. 1d). The 
growth rate of trees plays an important role in determining the SG (Suzuki 1999). In general, high growth rate in tropical trees is associated with low SG of wood (Suzuki 1999, MullerLandau 2004), and low growth rate is associated with high SG of wood (Van Gelder et al. 2006). However, this behavior usually occurs in species with diffuse porosity (Zobel and Van Buijtenen 1989), but in annular or semi-annular species, as C. odorata the behavior is different. This behavior occurs because the region that presents ring porosity is relatively constant, while the region with diffuse porosity is proportional to the width of the ring, therefore, the wider rings contain more diffuse porosity region, resulting in a higher density (Zobel and Van Buijtenen 1989).

The differences in flexural MOR and MOE result from the direct relationship between SG and these parameters (Muller-Landau 2004). The highest value of SG in 9-tree-agroforestry and 10-tree-agroforestry conditions results in greater flexural MOR and MOE in trees under those growth conditions (Tabs. 2 and 4). In the case of extractives soluble in ethanol-toluene, differences were observed only between 9-tree-agroforestry and 10-tree-plantation. Extractives depend on the age of the heartwood formation; therefore, greater quantity can be found in older trees (Tenorio and Moya 2019). Although not every part of the tree was sampled (heartwood/ sapwood) nor the age of formation of the heartwood was determined, it is likely that heartwood in trees in 10-year-old plantations contain more extractives than trees in 9-tear-old plantations.

\section{Chemical properties}

As for the chemical properties, significant differences were observed only in ethanoltoluene soluble compounds, where 9-tree-agroforestry condition differed from both 10-treeagroforestry and 10-tree-plantation conditions. The condition 10-tree-agroforestry showed no statistical differences with 10-tree-plantation. Condition 9-tree-agroforestry had the highest statistical values for hot water-soluble compounds and the lowest value for ethanol-toluene soluble compounds (Tab. 4). The other chemical components (cellulose, lignin, dichloromethane soluble compounds, $\mathrm{NaOH}$, hot water and amount of $\mathrm{N}, \mathrm{C}$ and $\mathrm{H}$ ) did not show statistical differences in the different plantations (Tab. 4).

Tab. 4: Averages of physical, mechanical and chemical properties of Cedrela odorata from trees growing in an agroforestry system with Theobroma cacao and growing in pure plantation.

\begin{tabular}{|c|l|c|c|c|}
\hline $\begin{array}{c}\text { Wood } \\
\text { properties }\end{array}$ & \multicolumn{1}{|c|}{ Parameters } & $\begin{array}{c}\text { 9-tree- } \\
\text { agroforestry }\end{array}$ & $\begin{array}{c}10 \text {-tree- } \\
\text { agroforestry }\end{array}$ & $\begin{array}{c}10 \text { - tree- } \\
\text { plantation }\end{array}$ \\
\hline \multirow{5}{*}{ Physical } & Specific gravity & $0.32^{\mathrm{A}}(13.1)$ & $0.31^{\mathrm{A}}(13.4)$ & $0.29^{\mathrm{B}}(12.0)$ \\
\cline { 2 - 5 } & Green density $\left(\mathrm{g} \cdot \mathrm{cm}^{-3}\right)$ & $0.58^{\mathrm{A}}(14.3)$ & $0.57^{\mathrm{A}}(13.6)$ & $0.60^{\mathrm{A}}(10.5)$ \\
\cline { 2 - 5 } & Green moisture content $(\%)$ & $82.23^{\mathrm{A}}(17.6)$ & $83.09^{\mathrm{A}}(27.6)$ & $108.15^{\mathrm{A}}(14.2)$ \\
\cline { 2 - 5 } & Volumetric shrinking $(\%)$ & $8.97^{\mathrm{A}}(15.0)$ & $8.95^{\mathrm{A}}(18.9)$ & $9.54^{\mathrm{A}}(19.1)$ \\
\cline { 2 - 5 } & Tangential shrinking (\%) & $4.25^{\mathrm{A}}(10.7)$ & $4.62^{\mathrm{A}}(11.8)$ & $5.01^{\mathrm{A}}(19.7)$ \\
\cline { 2 - 6 } & Radial shrinking (\%) & $3.11^{\mathrm{A}}(23.5)$ & $2.80^{\mathrm{A}}(16.2)$ & $3.54^{\mathrm{A}}(17.5)$ \\
\hline
\end{tabular}


Vol. 66 (1): 2021

\begin{tabular}{|c|c|c|c|c|c|}
\hline \multirow{8}{*}{ Mechanical } & \multirow{2}{*}{ Janka hardness } & Lateral (N) & $1418.3^{\mathrm{A}}(18.8)$ & $1458.0^{\mathrm{A}}(21.8)$ & $1283.0^{\mathrm{A}}(27.2)$ \\
\hline & & Axial (N) & $1704.5^{\mathrm{A}}(17.9)$ & 2002.2B (11.4) & $1485.1^{\mathrm{A}}(27.2)$ \\
\hline & \multirow[t]{2}{*}{ Shear } & $\begin{array}{l}\text { Tangential stress } \\
(\mathrm{MPa}) \\
\end{array}$ & $6.78^{\mathrm{A}}(11.4)$ & $6.77 \mathrm{~A}(11.2)$ & $6.65^{\mathrm{A}}(17.9)$ \\
\hline & & Radial stress $(\mathrm{MPa})$ & $6.10^{\mathrm{A}}(15.0)$ & $6.36^{\mathrm{A}}(8.7)$ & $6.34^{\mathrm{A}}(14.4)$ \\
\hline & \multirow{2}{*}{ Flexion } & $\begin{array}{l}\text { Module of rupture } \\
(\mathrm{MPa})\end{array}$ & $28.98^{\mathrm{A}}(13.4)$ & $30.23^{\mathrm{A}}(11.7)$ & $24.56^{\mathrm{B}}(12.4)$ \\
\hline & & $\begin{array}{l}\text { Module of elasticity } \\
(\mathrm{GPa})\end{array}$ & $4.07 \mathrm{~A}(12.3)$ & $4.46^{\mathrm{A}}(8.5)$ & $3.70^{\mathrm{B}}(11.9)$ \\
\hline & Compression & Stress $(\mathrm{MPa})$ & $16.35^{\mathrm{A}}(15.0)$ & $17.19^{\mathrm{A}}(21.3)$ & $16.82^{\mathrm{A}}(20.9)$ \\
\hline & Tension & Stress $(\mathrm{MPa})$ & $41.30^{\mathrm{A}}(32.3)$ & $40.46^{\mathrm{A}}(35.0)$ & $49.44^{\mathrm{A}}(38.4)$ \\
\hline \multirow{10}{*}{ Chemical } & \multicolumn{2}{|l|}{ Cellulose (\%) } & $53.00^{\mathrm{A}}(3.4)$ & $52.50^{\mathrm{A}}(1.6)$ & $51.83^{\mathrm{A}}(1.8)$ \\
\hline & \multicolumn{2}{|l|}{ Lignin (\%) } & $30.89^{\mathrm{A}}(0.9)$ & $30.72^{\mathrm{A}}(2.6)$ & $28.64^{\mathrm{A}}(5.4)$ \\
\hline & \multicolumn{2}{|c|}{ Extracts in dichloromethane (\%) } & $3.33^{\mathrm{A}}(37.4)$ & $2.33^{\mathrm{A}}(40.4)$ & $1.67^{\mathrm{A}}(56.6)$ \\
\hline & \multicolumn{2}{|c|}{ Extracts in $\mathrm{NaOH}(\%)$} & $3.50^{\mathrm{A}}(11.7)$ & $3.50^{\mathrm{A}}(35.0)$ & $4.00^{\mathrm{A}}(30.6)$ \\
\hline & \multicolumn{2}{|c|}{ Extracts in hot water (\%) } & $7.50^{\mathrm{A}}(10.9)$ & $5.00^{\mathrm{A}}(21.6)$ & $5.67 \mathrm{~A}(16.6)$ \\
\hline & \multicolumn{2}{|c|}{ Extracts in cool water (\%) } & $4.17^{\mathrm{A}}(2.9)$ & $4.17^{\mathrm{A}}(15.0)$ & $4.83^{\mathrm{A}}(34.1)$ \\
\hline & \multicolumn{2}{|c|}{ Extracts in ethanol-toluene (\%) } & $7.33^{\mathrm{A}}(12.7)$ & $12.00^{\mathrm{B}}(0.0)$ & $11.33^{\mathrm{B}}(8.3)$ \\
\hline & \multicolumn{2}{|c|}{ Nitrogen $(\%)$} & $0.15^{\mathrm{A}}(0.1)$ & $0.13^{\mathrm{A}}(0.0)$ & $0.18^{\mathrm{A}}(0.0)$ \\
\hline & \multicolumn{2}{|l|}{ Carbon (\%) } & $45.58^{\mathrm{A}}(0.7)$ & $45.65^{\mathrm{A}}(0.2)$ & $45.69^{\mathrm{A}}(1.0)$ \\
\hline & \multicolumn{2}{|l|}{ Hydrogen (\%) } & $6.34^{\mathrm{A}}(0.3)$ & $6.35^{\mathrm{A}}(0.6)$ & $6.36^{\mathrm{A}}(1.0)$ \\
\hline
\end{tabular}

Note: Different letters between ages and same wood properties means statistically different at $99 \%$. The values between parentheses represent the coefficients of variation.

\section{Energy properties}

According to the evaluation of the energy properties, the variables volatile percentage (Fig. 2a), ash (Fig. 2b) and calorific power (Fig. 2c) presented no significant differences between the three plantations analyzed.

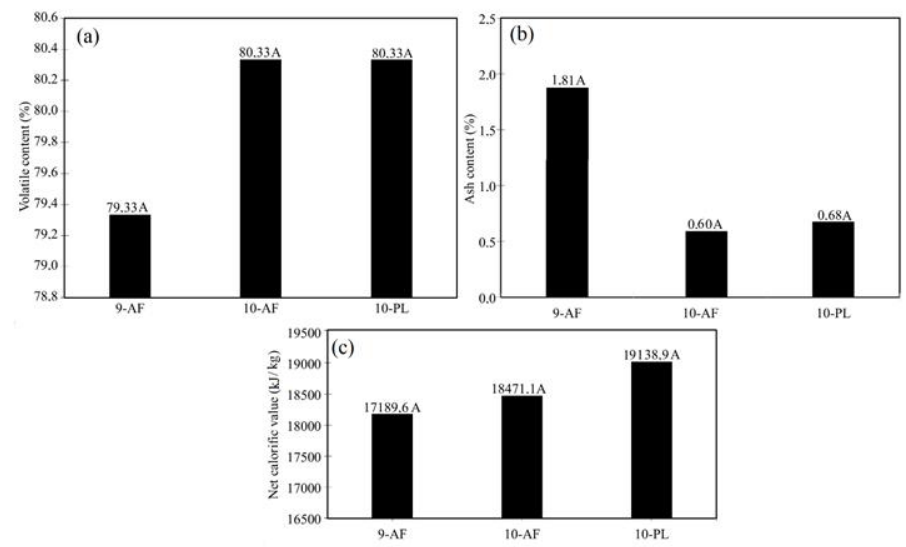

Fig. 2: Volatile and ash contents and net calorific value of Cedrela odorata from trees growing in agroforestry with Theobroma cacao and growing in pure plantation. 
The general, physical, mechanical and chemical properties of wood from C. odorata trees growing in agroforestry systems with $T$. cacao present few differences with the properties of wood of trees from a pure plantation, except for some parameters. Specifically, trees in agroforestry systems feature greater diameter and greater heartwood diameter and higher heartwood percentage, lower sapwood and bark percentage, lower SG, greater modulus of rupture and modulus of elasticity and higher extractives in cold water and in ethanol-toluene solution (Tabs. 2-4 and Fig. 1). These differences can be explained relative to the growth rate characteristic of trees in agroforestry systems.

The parameters evaluated in this research showed the potential of agroforestry systems relative to pure plantations, as regards to differences in tree growth produced by crop fertilization (in this case cocoa), pruning and other management measures to which the agricultural crop is subjected, which can give the wood qualities different from those found at earlier ages. Apart from the increase in diameter, some other important properties, specifically, heartwood and SG that relate to durability and structural strength were improved in trees growing in agroforestry systems. This would imply that wood from trees from agroforestry conditions present better condition, i.e., is more valuable, than wood from pure plantations. This result found for wood of agroforestry systems and pure plantations contradicts the assertion of Kouakou et al. (2016), who indicate that wood extracted from agroforestry systems has a higher proportion of juvenile wood, lower mechanical resistance, inadequate drying behavior, low durability and a higher proportion of reaction wood (lower quality), conditions that were not found in C. odorata trees growing in agroforestry systems.

\section{CONCLUSIONS}

It was found that the dasometric properties of trees growing in agroforestry systems show differences with those of trees growing in pure plantations. There are differences in the total diameter, percentage of bark, percentage of sapwood, diameter and percentage of heartwood, physical and mechanical properties and chemical and energy are not affected. In general, trees wood from trees growing agroforestry system presented better properties than wood from trees under pure plantations. According with these results, the potential of agroforestry systems relative to pure plantations, as regards to differences in tree growth produced by crop fertilization (in this case cocoa), pruning and other management measures to which the agricultural crop is subjected, which can give the wood qualities different from those found at earlier ages. This would imply that wood from trees from agroforestry conditions present better condition, i.e., is more valuable, than wood from pure plantations.

\section{ACKNOWLEDGMENTS}

The authors are grateful for the support of the Vicerrectoría de Investigacion y Extension of the Instituto Tecnológico de Costa Rica and also of Hacienda Azul S.A., whocontributed the materials for this research. The authors thank María Teresa Vargas L. for translating and editing to English. 


\section{REFERENCES}

1. ASTM D134 (2014): Standard test method for small clear specimens of timber.

2. ASTM D1110 (2013a): Standard test methods for water solubility of wood.

3. ASTM D1109(2013b): Standard test method for $1 \%$ sodium hydroxide solubility of wood.

4. ASTM D1107-96 (2013): Standard test method for ethanol-toluene solubility of wood.

5. ASTM D1108-96 (2013d): Standard test method for dichloromethane soluble in wood.

6. ASTM D1102-84 (2013e): Standard test method for ash in wood.

7. ASTM D1762-84 (2013f): Standard test method for chemical analysis of wood charcoal.

8. ASTM D5865-11 (2013g): Standard test method for gross calorific value of coal and coke.

9. Bárcenas-Pazos, G.M., Ortega-Escalona, F., Ángeles-Álvarez, G., Ronzón-Pérez, P., 2014: Relación estructura-propiedades de la madera de angiospermas mexicanas (Structureproperties relationship of the wood of Mexican angiosperms). Ecosistemas y Recursos Agropecuarios 21(42): 45-55.

10. Cordero, J., 2004: Árboles de Centroamérica: un Manual para extensionistas (Trees of Central America: A manual for extension workers). Turrialba, CATIE, 1058 pp.

11. Jaimez, R.E., Araque, O., Guzmán, D., Mora, A., Espinoza W., Tezara, W., 2013: Agroforestry systems of timber species and cacao: survival and growth during the early stages. Journal of Agriculture and Rural Development in the Tropics and Subtropics 114(1): $1-11$.

12. Kouakou, S.S., Marchal, R., Brancheriau, L., Guyot, A., Guibal, D., 2016: The quality of poplar wood from agroforestry: a comparison with forest plantation. In: Gosme M (ed) $3^{\text {rd }}$ European agroforestry conference. Montpellier, France, Pp 274-276.

13. Leyva, R.R., Erguera, M.L.C., 2014: Cedar (Cedrela odorata L.) development in an agroforestry system in Yucatán, México. Revista Forestal Baracoa 33: 148-156.

14. Moya, R., Muñoz, F., 2010: Physical and mechanical properties of eight fast-growing plantation species in Costa Rica. Journal Tropical of Forest Science 22(3): 317-328.

15. Montagnini, F., Nair, P.K.R., 2004: Carbon sequestration: an underexploited environmental benefit of agroforestry systems. Agroforestry Systems 61(1-3): 281-295.

16. Moya, R., Bond, B., Quesada, H., 2014: A review of heartwood properties of Tectona grandis trees from fast- growth plantations. Wood Science Technology 48(2): 411-433.

17. Muller-Landau., H.C., 2004: Interspecific and inter-site variation in wood specific gravity of tropical trees. Biotropica 36(1): 20-32.

18. Paine, Ch., Stahl, C., Courtois, E., Patino, S., Sarmiento, C., Baroloto, Ch., 2010: Functional explanations for variation in bark thickness in tropical rain forest trees. Function Ecology 24: 1202-1210.

19. Rigg-Aguilar, P., Moya, R., 2018: Properties of wood from 7-year-old Cedrela odorata trees of two different populations growing in agroforestry systems with Theobroma cacao. Madera y Bosques 24(1):1-13.

20. Seifert, K., 1960: Zur frage der Cellulose-Schnellbestimmung nach der AcetylacetonMethode. Das Papier 14: 104-106.

21. Somarriba, E., Suárez-Islas, A., Calero-Borge, W., Villota, A., Castillo, C., Vílchez, S., Deheuvels, O., Cerda, R. 2014: Cocoa-timber agroforestry systems: Theobroma cacaoCordia alliodora in Central America. Agroforestry Systems 88(6): 1001-1019.

22. Somarriba, E., Beer, J., 2011: Productivity of Theobroma cacao agroforestry systems with timber or legume service shade trees. Agroforestry Systems 81: 109-121. 
23. Somarriba, E., Cerda, R., Orozco, L., Dávila, M., Cifuentes, H., Astorga, T., Espinoza, C., 2013: Carbon stocks and cocoa yields in agroforestry systems of Central. America. Agriculture, Ecosystems and Environment 173: 46-57.

24. Suzuki, E. 1999: Diversity in specific gravity and water content of wood among Bornean tropical rainforest trees. Ecology Research 14(3): 211-224.

25. TAPPI, T222 om-02: Standard test for aci-insoluble lignin in wood and pulp (2002). Technical Association of Pulp and Paper Industry, Norcross (GA), 3pp.

26. Taylor, A.M., Gartner, B.L., Morrell, J.J., 2002: Heartwood formation and natural durability- a review. Wood Fiber Science 34(4): 587-611.

27. Tenorio, C., Moya, R., 2019: Evaluation of wood properties of four ages of Cedrela odorata trees growing in agroforestry systems with Theobroma cacao in Costa Rica. Agroforestry Systems 93(3): 973-988.

28. Tixier, P., Salazar-Díaz, R., 2019: Effect of plant diversity on income generated by agroforestry systems in Talamanca, Costa Rica. Agroforestry Systems 93(2): 571-580.

29. Tscharntke, T., Clough, Y., Bhagwat, S., Buchori, D., Faust, H., Hertel, D., Scherber, C., 2011: Multifunctional shade- tree management in tropical agroforestry lanscapes: a review. Journal Applied Ecology 48(3): 619-626.

30. Van Gelder, H.A., Poorter, L., Sterk, F.J., 2006: Wood mechanics, allometry and lifehistory variation in a tropical rain forest tree community. New Phycologist 171(2): 367-378.

31. Venson, I., Guzmán, J.S., Talavera, F.F., Richter, H.G., 2008: Biological, physical and mechanical wood properties of paraíso (Melia azedarach) from a roadside planting at Huaxtla, Jalisco, Mexico. Journal of Tropical Forest Science 20(1): 38-47.

32. Wilson, B.G., Witkowski, E.T.F., 2003: Seed banks, bark thickness and change in age and size structure (1978-1999) of the African savanna tree, Burhea africana. Plant Ecology 167: 151-162.

33. Zobel, B.J., Van Buijtenen, J.P., 1989: Wood variation: its causes and control. Springer Science \& Business Media, New York, 890 pp.

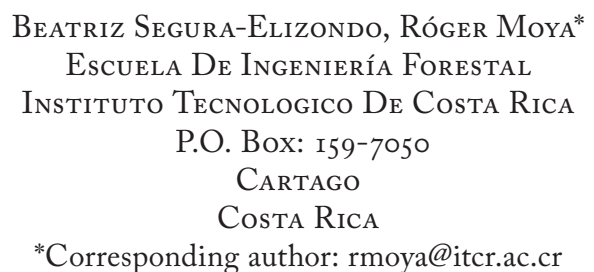

